\title{
High-Intensity Focused Ultrasound Ablation of Uterine Fibroids - Potential Impact on Fertility and Pregnancy Outcome
}

\author{
Myombehandlung mittels hochintensiviertem fokussiertem Ultraschall - \\ mögliche Auswirkung auf Fertilität und Schwangerschaftsausgang
}

Authors

Affiliations
M. K. Bohlmann ${ }^{1}$, F. Hoellen ${ }^{1}$, P. Hunold ${ }^{2}$, M. David ${ }^{3}$

Department of Obstetrics and Gynaecology, University Hospital Schleswig-Holstein - Campus Lübeck, Lübeck

2 Clinic for Radiology and Nuclear Medicine, University Hospital Schleswig-Holstein - Campus Lübeck, Lübeck

3 Klinik für Gynäkologie, Charité Campus Virchow-Klinikum, Berlin

\section{Key words \\ - pregnancy \\ - radiotherapy \\ - sterility \\ ultrasound \\ uterus \\ uterine tumor \\ Schlüsselwörter \\ - Schwangerschaft \\ - Radiotherapie \\ - Sterilität \\ - Ultraschall \\ - Uterus}

\section{Deutschsprachige} Zusatzinformationen online abrufbar unter: www.thieme-connect.de/ ejournals/toc/gebfra

\section{received $\quad 4.9 .2013$ \\ revised $\quad 11.11 .2013$ \\ accepted 21.12.2013}

\section{Bibliography}

DOI http://dx.doi.org/

10.1055/s-0033-1360311

Geburtsh Frauenheilk 2014; 74 :

139-145 @ Georg Thieme

Verlag KG Stuttgart · New York ISSN 0016-5751

\section{Correspondence}

\section{Privatdozent Dr. med.}

Michael K. Bohlmann

University Hospital Schleswig-

Holstein - Campus Lübeck

Department of Obstetrics

and Gynaecology

Ratzeburger Allee 160

23538 Lübeck

michael.bohlmann@uksh.de

\section{Abstract \\ $\nabla$}

Laparoscopic myomectomy is regarded as the gold standard for women with symptomatic fibroids who wish to become pregnant. High-intensity focused ultrasound (HIFU or MRgFUS) ablation of uterine fibroids is also being discussed as a non-surgical, minimally invasive, therapeutic option. This review examines the available data on the impact of HIFU/MRgFUS on fertility and pregnancy, focusing particularly on potential direct side-effects of this type of intervention on ovaries, fallopian tubes and uterus and potential late effects on pregnancy and birth, based on the current literature. All pregnancies after HIFU/ MRgFUS published to date (around 100 cases) were evaluated. The published case series suggest that HIFU/MRgFUS ablation has no impact on the rate of miscarriages or other obstetrical outcome parameters. Because no prospective studies exist which permit firm conclusions to be drawn on the impact of HIFU/MRgFUS on fertility and pregnancy outcome in women with symptomatic fibroids, this approach is currently only recommended for women with suspected fertility problems due to uterine fibroids who either decline surgery or who have an unacceptably high surgical risk.

\section{Introduction \\ $\nabla$}

Uterine fibroids are benign, hormone-sensitive tumours of the smooth muscles; the incidence in women of child-bearing age has reported to be as high as $40 \%$, depending on age [1-2]. Fibroids are considered the most common benign uterine tumours in women of reproductive age. Associated

\section{Zusammenfassung \\ $\nabla$}

Als Therapiestandard für Frauen mit Kinderwunsch und symptomatischen Myomen wird die möglichst wenig invasive operative Myomenukleation angesehen. Die Myombehandlung mit hochintensiviertem fokussiertem Ultraschall (HIFU/MRgFUS) wird als minimalinvasive Therapiemöglichkeit ebenfalls diskutiert. Diese Übersichtsarbeit wertet die vorhandene Literatur zum Thema „Einfluss von HIFU/MRgFUS auf Fertilität und Schwangerschaft" aus, wobei sowohl mögliche direkte Nebenwirkungen der Intervention an sich auf Ovarien, Tuben und Uterus als auch mögliche spätere Auswirkungen auf Schwangerschaft und Geburt auf der Basis der vorliegenden Literatur ausführlich diskutiert werden. Die bisher publizierten knapp 100 Schwangerschaften nach HIFU/MRgFUS wurden ausgewertet. Die vorliegenden Fallserien legen nahe, dass eine HIFU/ MRgFUS-Behandlung keinen Einfluss auf Abortrate sowie weitere geburtshilfliche Outcome-Parameter ausübt. Dennoch kann eine solche Therapie bis dato nur denjenigen Frauen mit vermuteten myomassoziierten Fertilitätsproblemen empfohlen werden, die chirurgische Maßnahmen ablehnen oder ein inakzeptabel hohes chirurgisches Risiko aufweisen, da keine prospektiven Studien vorliegen, die eine Aussage über den Einfluss der HIFU/MRgFUS-Therapie auf Fertilitätsrate und Schwangerschaftsausgang bei Frauen mit symptomatischen Myomen zulassen.

symptoms include dysmenorrhoea, spotting, hypermenorrhoea leading to anaemia, lower abdominal pain, pressure on adjacent organs and disorders of micturition and defecation [3]. The presence of uterine fibroids has a particularly important impact on women who may desire to become pregnant, as fibroids can negatively affect fertility. Sterility and a higher risk of complica- 
tions in pregnancy have both been associated with uterine fibroids [4]. Submucosal and intramural fibroids which distort the endometrial cavity are considered to impair fertility [5]. Intramural fibroids which distort the uterine cavity have also been found to reduce implantation and pregnancy rates [6], while surgical excision of submucosal fibroids resulted in higher rates for implantation and pregnancies carried to term [7]. Thus, despite the lack of prospective randomised studies comparing outcomes with those of untreated controls, [8] surgical enucleation is considered the gold standard for patients with symptomatic fibroids wanting to have children [9-10]. The choice of approach (hysteroscopy, laparoscopy or open abdominal surgery) depends on the location and size of the fibroid. Conservative medical approaches such as $\mathrm{GnRH}$-analogues or ulipristal acetate administration, hormone-releasing intrauterine devices, progesteronebased oral contraceptives, etc. can improve individual fibroid-related symptoms, but they can significantly delay pregnancy, often have only a temporary effect, or have not been approved for this application [3]. Although interventional radiology has been shown to be clinically effective in the treatment of uterine fibroids, the data show that complication rates in subsequent pregnancies are higher, indicating that uterine artery embolization (UAE) is unsuitable as a routine treatment for patients wanting to have children [11-13]. Similarly, a consensus meeting by a German panel of experts came to the conclusion that UAE should only be considered as a last resort in women requiring treatment to have children [14].

Treatment of fibroids using high-intensity focused ultrasound (HIFU; synonym: MRgFUS = magnetic resonance-guided focused ultrasound) is an organ-sparing, non-invasive, thermoablative procedure applied transcutaneously. In this procedure, the fibroid is gradually heated under continuous MRI monitoring in small, focussed stages, until temperatures $>55^{\circ} \mathrm{C}$ are reached to achieve complete denaturation of the localised tumour. The high energy concentration in a very small, ellipsoid focus to create discrete areas of tissue necrosis preserves both adjacent tissue and the structures between the energy source and the target tissue [15]. The effectiveness of HIFU/MRgFUS treatment can be increased even further using feedback regulation during volumetric ablation [16]. HIFU/MRgFUS procedures can be done on an outpatient basis without anaesthesia. HIFU/MRgFUS is much less invasive compared to surgical procedures. In clinical practice, HIFU treatment is offered as a potential therapeutic option to women of childbearing age with symptomatic fibroids who may wish to have children. It is therefore important to discuss HIFU/ MRgFUS as a potential treatment option.

The use of MRgFUS to treat fibroids was approved in the USA in 2004. The method was accorded a European CE (conformité européenne) mark in 2002 [15]. The procedure is generally considered to be effective and safe [17-22]; to date, around $10000 \mathrm{HI}-$ FU/MRGFUS procedures have been performed worldwide to treat women presenting with symptomatic uterine fibroids [23].

There is still some uncertainty in clinical practice requiring further interdisciplinary discussion about the use of HIFU/MRgFUS as a treatment option for women who have not yet completed their families. It is possible for women to become pregnant after undergoing HIFU/MRgFUS treatment [24]. However, the German consensus recommendations explicitly state that there is insufficient data to make any recommendation for or against the use of planned HIFU/MRgFUS treatment in women who wish to have children [25].
In analogy to a previous article published in this journal on fertility-related aspects of fibroid embolization, [11], this review aims to examine to what extent HIFU/MRgFUS treatment affects fertility and pregnancy. The review discusses potential, fertility-limiting injuries to the ovaries and uterus associated with the procedure as well as the possible impact on pregnancy and births based on the literature since the first publication of a pregnancy after MRgFUS treatment [26] and concludes with recommendations based on this discussion.

\section{Material and Methods}

$\nabla$

A systematic PubMed analysis was done to assess the impact of HIFU/MRgFUS treatment on fertility in women with uterine fibroids. The search was done using the term "fibroid" combined with the keywords "HIFU", "MRgFUS", "ultrasound ablation" and "pregnancy", "miscarriage" and "fertility" (date of retrieval August 1st, 2013). Out of the initial total of 47 articles, publications referring to non-human settings $(n=4)$ were excluded as were publications on HIFU use to abort pregnancy $(n=1)$ and the use of HIFU to treat men $(n=2)$. The remaining publications $(n=40)$ were then analysed further. There were no restrictions with regard to publication dates.

\section{Implementation, Therapeutic Success and Side-effects of HIFU Treatment $\nabla$}

The indications for HIFU/MRgFUS treatment are basically the same as for surgical removal of fibroids - only patients suffering from fibroid-related symptoms should receive treatment. It is important to note that clinical or technical exclusion criteria mean that fewer than half of all patients with fibroids are considered eligible for HIFU/MRgFUS treatment [27]. Whether HIFU/ MRgFUS treatment can be a treatment option for women with subfertility caused by uterine fibroids is discussed below. Two companies currently offer therapy units for such procedures; the units have been available for varying lengths of time (MRgFUS GE/Insightec since 2004; HIFU - Philips since 2010).

A preparatory MRI with contrast medium (CM) must be done, preferably with the patient in a ventral position, prior to carrying out the HIFU/MRgFUS procedure to determine the exact position of adjacent organs, the perfusion of the targeted fibroid and a suitable ultrasound window for the approach. A special patient table mounted with an ultrasound transducer is required for HIFU/MRgFUS procedures. For treatment, the abdomen above the uterus is shaved and the patient is placed face downward on the table of the HIFU/MRgFUS therapy unit. After controlling that the uterus is positioned centrally to the ultrasound transducer above the Plexiglas window ( $\bullet$ Fig. 1), a gel pad is applied between the Plexiglas window and the abdomen for acoustic coupling to the ultrasound transducer. The patient table is then moved into the scanner. MRI monitoring is done repeatedly to ensure that the uterus remains in the correct position above the transducer and to ensure that there are no interposed intestinal loops. Fibroid sonication results in denaturation with subsequent diminution of fibroid tissue, although this contraction process can take several months. Contrast medium is administered post procedure to measure results; the non-perfused volume (NPV) of the fibroid serves as measure of success. International studies report a median NPV of between $36 \%$ (6 months post procedure) 


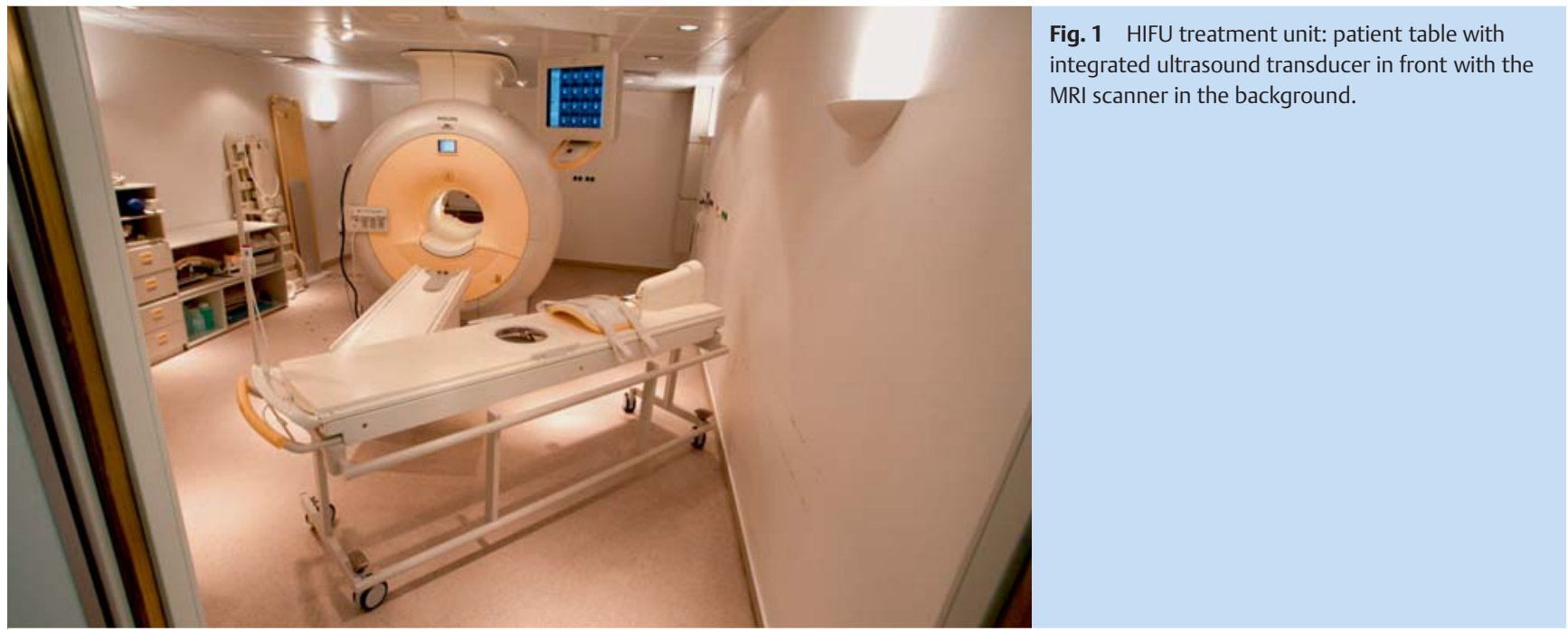

and 39\% (12 months post procedure) [28], which can rise to as high as 54\% (12 months post procedure) [29]. According to some of the older publications, this is associated with a mean decrease in fibroid volume of $10-15 \%$ after $6-12$ months [18,20,22], while a more recent publication reported a decrease of around 32\% after 3 years [30]. None of these studies was done as a prospective randomised trial.

Sonication close to the fibroid edge appears to play an important role in determining the extent of fibroid volume shrinkage [31]. But it should be noted that there is no linear relationship between the change in fibroid diameter and its volume, as fibroid volume is calculated using the formula $4 / 3 \pi r^{3}$ based on the assumption that the fibroid has a spherical shape. A decrease in fibroid diameter from 5 to $4 \mathrm{~cm}$ thus corresponds to an almost $50 \%$ decrease in volume. If it is assumed that the fibroid has an ellipsoid shape, then the volume of the fibroid would be calculated using the formula $1 / 6 \times \mathrm{d} 1 \times \mathrm{d} 2 \times \mathrm{d} 3 \times \pi$ with " $\mathrm{d}$ " representing the respective orthogonal diameters of the fibroid [32]. Controlling symptoms is more important than merely reducing fibroid volumes: HIFU/MRgFUS treatment resulted in higher levels of patient satisfaction [33]. In a retrospective study of 130 women, the rates for relief of symptoms (bleeding disorders, feeling of pressure, etc.) were $86 \%, 93 \%$ and $88 \%$ at 3,6 and 12 months post procedure, respectively [34]. A prospective study with a follow-up of 3 years demonstrated the long-lasting impact of HIFU/MRgFUS treatment using a standardised questionnaire to measure quality of life [30]. According to the data of a German study group, the technical success rate for HIFU/MRgFUS treatments of uterine fibroids is more than $90 \%$, while around $11 \%$ required additional treatment (hysterectomy, UAE) within a period of one year post procedure [35]. It should be noted that this cohort did not explicitly consist only of women who wished to have children, and it is therefore not possible to make any statement about the therapeutic effectiveness of HIFU/MRgFUS treatment for women who wish to have children.

Not all fibroids are suitable for HIFU/MRgFUS treatment. One study found that hyperintense fibroids on T2-weighted magnetic resonance imaging had lower long-term success rates after ultrasound ablation due to their higher perfusion (the heat is "dissipated" more quickly) [36]; success rates are similarly poor for septated, subserous or strongly dorsal fibroids close to the sacral nerves (shorter sonication times because of pain).
Potential side-effects or complications after HIFU/MRgFUS treatment as described below are actually quite rare (modified based on [25]):

- peri-interventional pain (usually low and of short duration), can usually be managed well with analgesia

- (slight) skin burns

- slight inflammation of subcutaneous fat tissue and of the abdominal muscles

- paraesthesia of the legs due to irritation of, or damage to, the nerves

- deep vein thrombosis of the legs (very rare)

- intestinal lesions or intestinal perforation (extremely rare)

- discharge of vaginal tissue

- increased and/or irregular bleeding for around 3 months post procedure

\section{Possible Negative Impact of HIFU Treatment on Fertility \\ $\nabla$}

\section{Exposure to radiation}

In contrast to fibroid embolization, the ovaries are not exposed to ionising radiation during HIFU/MRgFUS treatment. The procedure involves no risk of mutagenity.

\section{Adverse effect on ovarian and fallopian tube function}

The development of permanent amenorrhoea due to premature menopause would constitute a serious complication of any interventional treatment of fibroids using HIFU/MRgFUS. This could be caused by inadvertent direct sonication of the ovaries or if the uterine fibroid treated by sonication is too close to the ovaries. In fact, it is possible to induce a permanent loss of ovarian function by focussing HIFU/MRgFUS treatment directly on the ovaries [37]. However, these results obtained by a Chinese study group were done as part of study of targeted, non-surgical ovarian ablation in women with hormone receptor-positive breast cancer and cannot be considered as a complication of uterine focussed ultrasound treatment. Another group carried out a preliminary study into the serial use of HIFU/MRgFUS therapy to treat tubal pregnancy $(n=40): 64 \%$ of the treated tubes were found to be patent at 6 months post treatment, and the tubal patency rate was $82 \%$ at 12 months after treatment [38]. This fig- 
ures are comparable with the results after surgery or methotrexate administration [39]. There are no studies on changes in endocrine parameters or case reports of inadvertent iatrogenic ovarian failure or tubal occlusion after HIFU/MRgFUS treatment of uterine fibroids. In particular, no studies have been published to date on changes to anti-Müllerian hormone levels, an established marker of ovarian reserve. For technical reasons, HIFU/MRgFUS treatment always involves continuous MRI monitoring of the treated area and this alone precludes the inadvertent sonication of the ovaries.

\section{Adverse effect on uterine function}

Intramural fibroids can lead to disturbances in uterine contractility, and this has been proposed as a risk factor for sterility [40]. There are no data on the possible adverse impact on uterine function of HIFU/MRgFUS treatment. The change in position occurring during degeneration of the fibroid could also result in endometrial changes and changes in uterine contractility and thus lead to a loss of uterine functionality. There are no data on systematic hysteroscopic monitoring to exclude the presence of intracavitary adhesions after vaginal expulsion (post treatment) of fibroid tissue. In this case, due to the lack of studies the possibility cannot be excluded that HIFU/MRgFUS treatment could create a new risk factor for uterine sterility, similar to that demonstrated in a UAE cohort [41]. The possibility that sonication of adjacent tissue could have an adverse impact on the endometrium must also be considered: it is well known that one of the significant effects of sonication is based on intended injury to small blood vessels [42]. But, to date, there are not sufficient data which clearly demonstrate the impact of sonication, in particular of submucosal fibroids, on adjacent endometrial tissue and any impairment of implantation. This is important because (planned) sonication of the endometrium has been associated with clear morphological abnormalities [43].

\section{Pregnancy after HIFU/MRgFUS treatment}

- Table 1 provides an overview of all pregnancies occurring after HIFU/MRgFUS treatment published to date.

Several aspects must be given additional consideration in this context. It must be assumed that all pregnancies published before 2010 occurred in women who were treated using a treatment unit from the company GE/Insightec. As the review by Rabinovici et al. [24] published in 2010 is based on a registry held by this company, it is not possible to exclude the possibility that individual pregnancies were listed twice (e.g., as a case history and as part of the review), and at least in one case [44], this is highly probable (E. Stewart, pers. communication). Since then, the same authors have presented updated evaluations of the registry at various conferences with case numbers $>100$ [45-46], but these have not yet been published in full. The outcomes described in the presentations do not differ in any essentials from the study published in 2010. The inclusion of the results obtained with units from a second manufacturer in a common registry should make a systematic evaluation of higher numbers of pregnancies possible [47].

The work of a Chinese study group [48] which reported pregnancy outcomes after ultrasound ablation of uterine fibroids was also included in 0 Table 1. It should be noted that in this study target volumes were monitored sonographically and not using MRI; moreover the authors reported a high rate of elective abortions in subsequent pregnancies. The article does not indi- cate to what extent country-specific population policies could be partly responsible for the rate of elective abortions.

The literature on fertility after HIFU/MRgFUS treatment remains limited, but the existing literature appears to show that fertility may be preserved after HIFU/MRgFUS treatment [24]. Two important aspects which are strikingly different to uterine artery embolization done prior to pregnancy will be discussed in more detail below.

\section{Risk of miscarriage after HIFU}

In all statements on the rate of miscarriages in a post HIFU/ MRgFUS cohort, both the age of the mother and the "basic risk" of a miscarriage when fibroids are present in the uterus must also be taken into consideration, as both of these factors can independently have a negative impact on the rate of miscarriages. Hypothetically, changes in position during fibroid degeneration could even increase the risk of miscarriage, similar to results reported for UAE [49]. In contrast to the data available for UAE procedures [12], there are currently no comparative prospective data on women with fibroids who have not had HIFU treatment. But the largest published collection of case histories [24] included in - Table 1 shows that the risk of miscarriage after HIFU/MRgFUS does not appear to be significantly higher compared to an agematched control group of patients wanting to have children in the literature: the rate of miscarriages after IVF/ICSI reported for women wanting to have children is also around 20\% (- Table 2) [50].

\section{Obstetrical outcome after HIFU}

To answer the question whether pregnancies are at particular risk if the mother has previously had HIFU/MRgFUS treatment, we will need to look at the results of prospective randomised clinical trials. But no such trials comparing outcomes for women who did not have treatment and women who had uterine fibroid enucleation with outcomes for women treated with HIFU/ MRgFUS have been done to date. However, comparisons of current data with outcomes reported for historical cohorts [11] show that there are no indications of complication rates being higher intrapartum after HIFU/MRgFUS. It is also important to note that there are no reported cases of peripartal haemorrhage after HIFU/MRgFUS, in contrast to UAE where peripartal haemorrhage occurred after UAE due to significantly higher rates of placentation disorders [51]. It is also important to highlight the low rate of preterm births ( $<10 \%$ in all reports) and to mention the high rate of Caesarean sections, which are common clinical practice in industrialised countries ( Table 3 ). The rates of elective C-sections among women with fibroids treated with HIFU/ MRgFUS could be due to a wish expressed by the patient herself, to an increased need for safety or due to uncertainty on the part of the physician.

It is still unclear to what extent scarred areas in the uterus after HIFU/MRgFUS treatment will remain stable during labour. Given that rates of uterus rupture in a "normal cohort" of untreated women without uterine scarring are very low, further studies in larger cohorts are necessary. 
Table 1 Published reports of pregnancies after HIFU/MRgFUS treatment (modified, based on [23]; (n. s.: not specified; * absolute numbers have only limited significance because of possible double publication of data, " incomplete publication of some of the data).

\begin{tabular}{|c|c|c|c|c|c|c|c|c|c|}
\hline Reference & $\begin{array}{l}\text { Treated } \\
\text { patients }\end{array}$ & $\begin{array}{l}\text { Women } \\
\text { wishing } \\
\text { to have } \\
\text { children }\end{array}$ & $\begin{array}{l}\text { Pregnan- } \\
\text { cies }\end{array}$ & $\begin{array}{l}\text { Rate of } \\
\text { miscar- } \\
\text { riages }\end{array}$ & $\begin{array}{l}\text { Pregnan- } \\
\text { cies } \\
\text { carried } \\
\text { to term }\end{array}$ & $\begin{array}{l}\text { Age } \\
\text { (years) of } \\
\text { pregnant } \\
\text { women }\end{array}$ & $\begin{array}{l}\text { Rate of } \\
\text { preterm } \\
\text { births }\end{array}$ & $\begin{array}{l}\text { Rate of } \\
\text { Caesar- } \\
\text { ean sec- } \\
\text { tions }\end{array}$ & Characteristics \\
\hline $\begin{array}{l}\text { Gavrilova- } \\
\text { Jordan et al. } \\
\text { [55] }\end{array}$ & 1 & 1 & 1 & $0 \%(0 / 1)$ & $1(100 \%)$ & 40 & $0 \%(0 / 1)$ & $0 \%(0 / 1)$ & case report \\
\hline $\begin{array}{l}\text { Hanstede } \\
\text { et al. [44] }\end{array}$ & 1 & 1 & 1 & $0 \%(0 / 1)$ & $1(100 \%)$ & 40 & $0 \%(0 / 1)$ & $0 \%(0 / 1)$ & case report \\
\hline $\begin{array}{l}\text { Morita et al. } \\
\text { [56] }\end{array}$ & 1 & 1 & 1 & $0 \%(0 / 1)$ & $1(100 \%)$ & n.s. & $0 \%(0 / 1)$ & n.s. & case report \\
\hline $\begin{array}{l}\text { Funaki et al. } \\
\text { [28] }\end{array}$ & 80 & n.s. & 4 & $\begin{array}{l}50 \% \\
(2 / 4)\end{array}$ & $2(50 \%)$ & n.s. & $0 \%(0 / 2)$ & n.s. & case series \\
\hline $\begin{array}{l}\text { Rabinovici } \\
\text { et al. [24] }\end{array}$ & n.s. & n.s. & $\begin{array}{l}54 \text { (in } 51 \\
\text { women) }\end{array}$ & $\begin{array}{l}25.9 \% \\
(14 / 54)\end{array}$ & $22(41 \%)$ & $\begin{array}{l}28-49 \\
\text { (at the time } \\
\text { of HIFU } \\
\text { treatment) }\end{array}$ & $7 \%(4 / 54)$ & $\begin{array}{l}36 \% \\
(8 / 22)\end{array}$ & $\begin{array}{l}11 \text { ongoing preg- } \\
\text { nancies }>20 \mathrm{GW} \\
7 \text { elective abortions } \\
0 \text { SGA/IUGR }\end{array}$ \\
\hline $\begin{array}{l}\text { Zaher et al. } \\
\text { [57] }\end{array}$ & 1 & 1 & 1 & $0 \%(0 / 1)$ & $1(100 \%)$ & 39 & $0 \%(0 / 1)$ & $0 \%(0 / 1)$ & case report \\
\hline $\begin{array}{l}\text { Yoon et al. } \\
\text { [58] }\end{array}$ & 1 & 1 & 1 & $0 \%(0 / 1)$ & $1(100 \%)$ & 31 & $0 \%(0 / 1)$ & $0 \%(0 / 1)$ & case report \\
\hline $\begin{array}{l}\text { Bouwsma } \\
\text { et al. [59] }\end{array}$ & 1 & 1 & 1 & $0 \%(0 / 1)$ & $1(100 \%)$ & 37 & $0 \%(0 / 1)$ & $0 \%(0 / 1)$ & $\begin{array}{l}\text { case report s/p } \\
\text { several successful } \\
\text { inseminations prior } \\
\text { to HIFU }\end{array}$ \\
\hline $\begin{array}{l}\text { Millan Cantero } \\
\text { et al. [60] }\end{array}$ & 3 & 3 & $\begin{array}{l}4 \text { (in } 3 \\
\text { women) }\end{array}$ & $0 \%(0 / 4)$ & $4(100 \%)$ & $36-41$ & $0 \%(0 / 4)$ & $\begin{array}{l}25 \% \\
\text { (emergen- } \\
\text { cy C-sec- } \\
\text { tion) }(1 / 4)\end{array}$ & \\
\hline $\begin{array}{l}\text { Zaher et al. } \\
\text { [61] }\end{array}$ & 1 & 1 & $\begin{array}{l}1 \text { (1st IVF } \\
\text { cycle after } \\
\text { HIFU) }\end{array}$ & $0 \%(0 / 1)$ & $1(100 \%)$ & 45 & $0 \%(0 / 1)$ & $\begin{array}{l}100 \% \\
\text { (emergen- } \\
\text { cy C-sec- } \\
\text { tion) }(1 / 1)\end{array}$ & $\begin{array}{l}\text { case report s/p } \\
4 \text { unsuccessful IVF } \\
\text { attempts prior to } \\
\text { HIFU }\end{array}$ \\
\hline Qin et al. [48] & 435 & 8 & $\begin{array}{l}24 \text { (16 } \\
\text { women } \\
\text { with un- } \\
\text { planned } \\
\text { pregnan- } \\
\text { cies) }\end{array}$ & $\begin{array}{l}8.3 \% \\
(2 / 24)\end{array}$ & 7 & n.s. & n.s. & n.s. & $\begin{array}{l}15 \text { elective } \\
\text { abortions (Chinese } \\
\text { study group) }\end{array}$ \\
\hline $\begin{array}{l}\text { Kamp et al. } \\
\text { [35] }\end{array}$ & 54 & n.s. & 8 & $0 \%(0 / 8)$ & 7 & n.s. & n.s. & $43 \%(3 / 7)$ & 1 lost to follow-up \\
\hline $\begin{array}{l}\text { Total, insofar } \\
\text { as figures can } \\
\text { be calculated }\end{array}$ & $>579^{\#}$ & $>18^{\#}$ & $\leq 101^{*}$ & $\begin{array}{l}17.8 \% \\
(18 / \\
101)^{*}\end{array}$ & $\leq 49^{*}$ & $28-49^{\#}$ & $\begin{array}{l}\sim 5.9 \% \\
(4 / 67)^{*}, \#\end{array}$ & $\begin{array}{l}33.3 \% \\
(13 / 39)^{*, \#}\end{array}$ & $\begin{array}{l}11 \text { ongoing } \\
\text { pregnancies } \\
22 \text { abortions } \\
1 \text { lost to follow-up }\end{array}$ \\
\hline
\end{tabular}

Table 2 Comparison of abortion rates in this publication with a historical cohort (from [12] and cohort of women who had therapy to conceive [50]; (Table analogous to [11]).

\begin{tabular}{|llll} 
& $\begin{array}{l}\text { Evaluable pregnancies after } \\
\text { HIFU treatment }(\mathbf{n = 1 0 1 )}\end{array}$ & $\begin{array}{l}\text { Patients with untreated fibroids } \\
\mathbf{( n = 1 1 2 1 )}\end{array}$ & German IVF registry ( $\mathbf{n}=\mathbf{1 3 8 4 1 )}$ \\
\hline Number of miscarriages & 18 & 185 & $\begin{array}{l}2564 \\
\text { (excluding extrauterine pregnancies) }\end{array}$ \\
\hline Rate of miscarriages & $17.8 \%$ & $16.5 \%$ & $18.52 \%$
\end{tabular}

Table 3 Comparison of C-section and preterm birth rates in this paper with a historical control cohort of fibroid patients (from [12] and from a normal population giving birth in a hospital [53]; Table analogous to [11]).

\begin{tabular}{|llll} 
& Evaluable pregnancies after & Patients with untreated fibroids & Normal population ( $\mathbf{n}=\mathbf{3 4 7 1 1}$ ) \\
& HIFU treatment & & \\
\hline Caesarean section rate & $33.3 \%(13 / 39)$ & $48.5 \%(2098 / 4322)$ & $25.9 \%$ \\
\hline Preterm birth rate & $5.9 \%(4 / 67)$ & $16 \%(183 / 1145)$ & $9.1 \%$
\end{tabular}




\section{Conclusion}

$\nabla$

For patients who may potentially want to have children, the role of HIFU/MRgFUS as a treatment option for uterine fibroids has not yet been sufficiently clarified.

At present there are only a few retrospective studies and the results of these studies do not provide sufficient evidence for any statement to be made about the impact of HIFU/MRgFUS treatment on fertility rates and pregnancy outcomes. There are still no prospective comparative studies (fibroid enucleation vs. HIFU/MRgFUS), although the need for such studies was emphasised some time ago [52].

For people searching for information/women with fibroids who wish to have children, a statement whether HIFU/MRgFUS treatment is associated with additional reproductive risks or, instead, could potentially improve fertility is important.

While data from reviews and case histories of preoperative uterine artery embolization are available [53], similar information on the use of targeted preoperative HIFU/MRgFUS treatment to reduce fibroid size and bleeding tendency is currently still lacking. Based on the publications to date, the following preliminary conclusions can be drawn:

1. The currently existing but limited evidence does not suggest that HIFU/MRgFUS treatment should replace surgical fibroid removal as the method of choice for women who require treatment of their fibroids to improve fertility. This was confirmed again by the existing consensus recommendation.

2. For patients with symptomatic fibroids who may wish to have children in the future but do not immediately wish to have children, the data on the long-term impact of HIFU/MRgFUS treatment on fertility are still insufficient, but to date there is no evidence of any relevant impairment of fertility after HIFU/ MRgFUS treatment.

3. The existing case series of small patient cohorts offer no indications of an increased risk for miscarriage or increased rates of bleeding postpartum after prior HIFU/MRgFUS treatment.

4. Further studies of larger cohorts must focus particularly on the issue of whether scarred uterine tissue after HIFU/MRgFUS treatment remains stable during labour.

5. Currently, HIFU/MRgFUS treatment for fibroids can only be recommended to women with fibroid-associated subfertility who strictly reject surgical treatment or who have a very great or inacceptably high surgical risk. It should also be discussed whether pregnancies with their associated risks are justifiable in these women.

6. The data are still insufficient to answer the question whether a "latency period" before becoming pregnant to allow the fibroid to shrink or change its size should be recommended to patients treated in exceptional cases with HIFU/MRgFUS. Individual published cases have reported very short periods of just a few months [24] between HIFU/MRgFUS treatment and the start of a pregnancy successfully carried to term.

\section{Acknowledgement \\ $\nabla$}

We would like to thank Mr Oliver Kuty for his excellent photography.

\section{Conflict of Interest \\ $\nabla$}

PD Dr Hunold and PD Dr Bohlmann received speaker's fees from Philips HealthCare. Prof David and Dr Hoellen declare that they have no conflict of interest.

\section{References}

1 Wallach EE, Vlahos NF. Uterine myomas: an overview of development, clinical features, and management. Obstet Gynecol 2004; 104: 393406

2 Jacoby VL, Fujimoto VY, Giudice LC et al. Racial and ethnic disparities in benign gynecologic conditions and associated surgeries. Am J Obstet Gynecol 2010; 202: 514-521

3 Hoellen F, Griesinger G, Bohlmann MK. Therapeutic drugs in the treatment of symptomatic uterine fibroids. Expert Opin Pharmacother 2013; 14: 2079-2085

4 Islam MS, Protic O, Giannubilo SR et al. Uterine leiomyoma: available medical treatments and new possible therapeutic options. J Clin Endocrinol Metab 2013; 98: 921-934

5 Brady PC, Stanic AK, Styer AK. Uterine fibroids and subfertility: an update on the role of myomectomy. Curr Opin Obstet Gynecol 2013; 25: 255-259

6 Guven S, Kart C, Unsal MA et al. Intramural leoimyoma without endometrial cavity distortion may negatively affect the ICSI - ET outcome. Reprod Biol Endocrinol 2013; 11: 102

7 Pritts EA, Parker WH, Olive DL. Fibroids and infertility: an updated systematic review of the evidence. Fertil Steril 2009; 91: 1215-1223

8 Metwally M, Cheong YC, Horne AW. Surgical treatment of fibroids for subfertility. Cochrane Database Syst Rev 2012; 11: CD003857

9 van der Kooij SM, Ankum WM, Hehenkamp WJ. Review of nonsurgical/ minimally invasive treatments for uterine fibroids. Curr Opin Obstet Gynecol 2012; 24: 368-375

10 Guo XC, Segars JH. The impact and management of fibroids for fertility: an evidence-based approach. Obstet Gynecol Clin North Am 2012; 39: 521-533

11 David M, Kröncke T. Uterine fibroid embolisation - potential impact on fertility and pregnancy outcome. Geburtsh Frauenheilk 2013; 73: 247255

12 Homer H, Saridogan E. Uterine artery embolization for fibroids is associated with an increased risk of miscarriage. Fertil Steril 2010; 94: 324330

13 Goldberg J, Pereira L. Pregnancy outcomes following treatment for fibroids: uterine fibroid embolization versus laparoscopic myomectomy. Curr Opin Obstet Gynecol 2006; 18: 402-406

14 Kröncke T, David M. Uterine artery embolization (UAE) for fibroid treatment: results of the 4th Radiological Gynecological Expert Meeting. RoFo 2013; 185: 461-463

15 Griffiths A, ter Haar G, Rivens I et al. High-intensity focused ultrasound in obstetrics and gynecology: the birth of a new era of noninvasive surgery? Ultraschall in Med 2012; 33: E8-E15

16 Ruhnke H, Eckey T, Bohlmann MK et al. MR-guided HIFU treatment of symptomatic uterine fibroids using novel feedback-regulated volumetric ablation: effectiveness and clinical practice. Rofo 2013; 184: 983-991

17 Stewart EA, Gedroyc WM, Tempany CM et al. Focused ultrasound treatment of uterine fibroid tumors: safety and feasibility of a noninvasive thermoablative technique. Am J Obstet Gynecol 2003; 189: 48-54

18 Hindley J, Gedroyc WM, Regan L et al. MRI guidance of focused ultrasound therapy of uterine fibroids: early results. Am J Roentgenol 2004; 183: 1713-1719

19 Fennessy FM, Tempany CM. MRI-guided focused ultrasound surgery of uterine leiomyomas. Acad Radiol 2005; 12: 1158-1166

20 Stewart EA, Rabinovici J, Tempany CM et al. Clinical outcomes of focused ultrasound surgery for the treatment of uterine fibroids. Fertil Steril 2006; 85: 22-29

21 Stewart EA, Gostout B, Rabinovici J et al. Sustained relief of leiomyoma symptoms by using focused ultrasound surgery. Obstet Gynecol 2007; 110: $279-287$

22 Rabinovici J, Inbar Y, Revel $A$ et al. Clinical improvement and shrinkage of uterine fibroids after thermal ablation by magnetic resonanceguided focused ultrasound surgery. Ultrasound Obstet Gynecol 2007; 30: 771-777 
23 Bohlmann MK, Hunold P, Rabe T et al. Hochintensiver fokussierter Ultraschall. Neue diagnostische und therapeutische Optionen bei Patientinnen mit Myomen. J Reprod Endokrinol 2013; 10: 266-272

24 Rabinovici J, David M, Fukunishi H et al.; MRgFUS Study Group. Pregnancy outcome after magnetic resonance-guided focused ultrasound surgery (MRgFUS) for conservative treatment of uterine fibroids. Fertil Steril 2010; 93: 199-209

25 Beck A, David M, Kröncke T. Magnetresonanz-geführter fokussierter Ultraschall zur Myombehandlung - Ergebnisse des ersten radiologischgynäkologischen Expertentreffens. Fortschr Röntgenstr 2013; 185: 464-466

26 Rabinovici J, Inbar Y, Eylon SC et al. Pregnancy and live birth after focused ultrasound surgery for symptomatic focal adenomyosis: a case report. Hum Reprod 2006; 21: 1255-1259

27 Behera MA, Leong M, Johnson L et al. Eligibility and accessibility of magnetic resonance-guided focused ultrasound (MRgFUS) for the treatment of uterine leiomyomas. Fertil Steril 2010; 94: 1864-1868

28 Funaki K, Fukunishi H, Sawada K. Clinical outcomes of magnetic resonance-guided focused ultrasound surgery for uterine myomas: 24month follow-up. Ultrasound Obstet Gynecol 2009; 34: 584-589

29 Okada A, Morita Y, Fukunishi H et al. Non-invasive magnetic resonanceguided focused ultrasound treatment of uterine fibroids in a large Japanese population: impact of the learning curve on patient outcome. Ultrasound Obstet Gynecol 2009; 34: 579-583

$30 \mathrm{Kim}$ HS, Baik JH, Pham LD et al. MR-guided high-intensity focused ultrasound treatment for symptomatic uterine leiomyomata: long-term outcomes. Acad Radiol 2011; 18: 970-976

31 Fukunishi H, Funaki K, Sawada Ket al. Therapy of uterine myomas using MR-guided Focused Ultrasound Surgery (MRgFUS). A study of the nonenhanced areas around the myoma. Geburtsh Frauenheilk 2007; 67: 336-340

32 Ichimura $T$, Kawamura N, Ito $\mathrm{F}$ et al. Correlation between the growth of uterine leiomyomata and estrogen and progesterone receptor content in needle biopsy specimens. Fertil Steril 1998; 70: 967-971

33 Stovall DW. Alternatives to hysterectomy: focus on global endometrial ablation, uterine fibroid embolization, and magnetic resonanceguided focused ultrasound. Menopause 2011; 18: 437-444

34 Gorny KR, Woodrum DA, Brown DL et al. Magnetic resonance guided focused ultrasound of uterine leiomyomas: review of a 12-month outcome of 130 clinical patients. J Vasc Interv Radiol 2011; 22: 857-864

35 Kamp JE, David M, Scheurig-Muenkler C et al. Clinical outcome of magnetic-resonance-guided focused ultrasound surgery (MRgFUS) in the treatment of symptomatic uterine fibroids. Rofo 2013; 185: 136-143

36 Machtinger R, Cohen-Eylon S, Admon D et al. MR-guided focus ultrasound (MRgFUS) for symptomatic uterine fibroids: predictors of treatment success. Hum Reprod 2012; 27: 3425-3431

37 Wang SW, He XY, Li MZ. High-intensity focused ultrasound compared with irradiation for ovarian castration in premenopausal females with hormone receptor-positive breast cancer after radical mastectomy. Oncol Lett 2012; 4: 1087-1109

38 He GB, Luo W, Zhou XD et al. A preliminary clinical study on high-intensity focused ultrasound therapy for tubal pregnancy. Scott Med J 2011; 56: 214-219

39 Barnhart KT. Ectopic pregnancy. NEJM 2009; 361: 379-387

40 Yoshino 0 , Hayashi T, Osuga Y et al. Decreased pregnancy rate is linked to abnormal uterine peristalsis caused by intramural fibroids. Hum Reprod 2010; 25: 2475-2479
41 Mara M, Fucikova Z, Kuzel D et al. Hysteroscopy after uterine fibroid embolization in women of fertile age. J Obstet Gynaecol Res 2007; 33: 316-324

42 Dong $X$, Yang Z. High-intensity focused ultrasound ablation of uterine localized adenomyosis. Curr Opin Obstet Gynecol 2010; 22: 326-330

43 Fruehauf JH, Back W, Eiermann A et al. High-intensity focused ultrasound for the targeted destruction of uterine tissues: experiences from a pilot study using a mobile HIFU unit. Arch Gynecol Obstet 2008; 277 : 143-150

44 Hanstede MM, Tempany CM, Stewart EA. Focused ultrasound surgery of intramural leiomyomas may facilitate fertility: a case report. Fertil Steril 2007; 88: 497.e5-497.e7

45 Millan Cantero H. 2011. Online: http://www.insightec.com/Pregnancyresearch-ExAblate.html; last access: 01.08.2013

46 Rabinovici J. 2012. Online: http://www.insightec.com/Pregnancyresearch-ExAblate.html; last access: 01.08.2013

47 Online: http://www.fibroidrelief.org/registry/; last access: 01.08.2013

48 Qin J, Chen JY, Zhao WP et al. Outcome of unintended pregnancy after ultrasound-guided high-intensity focused ultrasound ablation of uterine fibroids. Int J Gynaecol Obstet 2012; 117: 273-277

49 Memtsa M, Homer $H$. Complications associated with uterine artery embolization for fibroid. Obstet Gynecol Int 2012; 2012: 290542

50 Online: http://www.deutsches-ivf-register.de/pdf-downloads/ dirjahrbuch2011-d.pdf; last access: 01.08.2013

51 Tropeano G, Amoroso S, Scambia G. Non-surgical management of uterine fibroids. Hum Reprod Update 2008; 14: 259-274

52 Gedroyc WM. MRgFUS: a sound approach to fibroid therapy. Ultrasound Obstet Gynecol 2009; 34: 494-496

53 David M, Kröncke T. Preoperative uterine artery embolisation for large uterine fibroids with subsequent uterus preservation - three case histories and review of the literature. Geburtsh Frauenheilk 2012; 72 : 539-542

54 BQS-Bundesgeschäftsstelle Qualitätssicherung gGmbH. Landesauswertung Qualitätssicherung Berlin, Berliner Klinikgeburten 2011. BQSHamburg 2012

55 Gavrilova-Jordan LP, Rose CH, Traynor KD et al. Successful term pregnancy following MR-guided focused ultrasound treatment of uterine leiomyoma. J Perinatol 2007; 27: 59-61

56 Morita Y, Ito N, Ohashi $\mathrm{H}$. Pregnancy following MR-guided focused ultrasound surgery for a uterine fibroid. Int J Gynaecol Obstet 2007; 99 : 56-57

57 Zaher S, Lyons D, Regan $L$. Uncomplicated term vaginal delivery following magnetic resonance-guided focused ultrasound surgery for uterine fibroids. Biomed Imaging Interv J 2010; 6: e28

58 Yoon SW, Kim KA, Kim SH et al. Pregnancy and natural delivery following magnetic resonance imaging-guided focused ultrasound surgery of uterine myomas. Yonsei Med J 2010; 51: 451-453

59 Bouwsma EV, Gorny KR, Hesley GK et al. Magnetic resonance-guided focused ultrasound surgery for leiomyoma-associated infertility. Fertil Steril 2011; 96: e9-e12

60 Millan Cantero H, Suárez Ramos J, García Laffitte E et al. First three cases in Spain of term pregnancy after treatment of uterine fibroid with noninvasive MRgFUS surgery. Prog Obstet Ginecol 2011; 54: 601-604

61 Zaher S, Lyons D, Regan L. Successful in vitro fertilization pregnancy following magnetic resonance-guided focused ultrasound surgery for uterine fibroids. J Obstet Gynaecol Res 2011; 37: 370-373 